\title{
MASTER
}

WAPD-TM-198

AEC RESEARCH AND DEVELOPMENT REPORT

\section{RECOIL RANGE OF FISSION FRAGMENTS IN ZIRCONIUM}

NOVEMBER 1959

CONTRACT AT-11-1-GEN-14

BETTIS ATOMIC POWER LABORATORY, PITTSBURGH, PA., OPERATED FOR THE U. S. ATOMIC ENERGY COMMISSION BY WESTINGHOUSE ELECTRIC CORPORATION 


\section{DISCLAIMER}

This report was prepared as an account of work sponsored by an agency of the United States Government. Neither the United States Government nor any agency Thereof, nor any of their employees, makes any warranty, express or implied, or assumes any legal liability or responsibility for the accuracy, completeness, or usefulness of any information, apparatus, product, or process disclosed, or represents that its use would not infringe privately owned rights. Reference herein to any specific commercial product, process, or service by trade name, trademark, manufacturer, or otherwise does not necessarily constitute or imply its endorsement, recommendation, or favoring by the United States Government or any agency thereof. The views and opinions of authors expressed herein do not necessarily state or reflect those of the United States Government or any agency thereof. 


\section{DISCLAIMER}

Portions of this document may be illegible in electronic image products. Images are produced from the best available original document. 


\title{
RECOIL RANGE OF FISSION FRAGMENTS IN ZIRCONIUM
}

\author{
E. R. Smith \\ P. W. Frank
}

\section{Contract AT-11-1-GEN-14}

November 1959

\section{Price $\$ .50$}

Available from the Office of Technical Services,

Department of Commerce,

Washington 25, D. C.

This document is an interim memorandum prepared primarily for internal reference and does not represent a final expression of the opinion of Westinghouse. When this memorandum is distributed externally, it is with the express understanding that Westinghouse makes no representation as to completeness, accuracy, or usability of information contained therein.

\section{BETTIS ATOMIC POWER LABORATORY}

PITTSBURGH, PENNSYIVANIA

OPERATED FOR THE U. S. ATOMIC ENERGY COMMISSION BY

WESTINGHOUSE ELECTRIC CORPORATION 
$\therefore \quad:$

\section{STANDARD EXTERNAL DISTRIBUTION}

UC-25: Metallurgy and Ceramics, TID-4500, 15th Edition
No. Copies

556

SPECIAL EXTERNAL DISTRIBUTION

Manager, Hittsburgh Naval Reactors Óperations Office, AEC.

F. T. Hobbs, l'echnical Cooperation Branch
Total $\frac{1}{570}$

\section{LEGAL NOTICE}

This report was prevared as an arrnunt nf government oponoored woik. Heillier the unized States, nor the Commission, nor any person acting on behalf of the Commission:

A. Makes añy warranty or representation, expressed or implied, with respoct to the accuracy, completeness, or usefulness of the information contained in this report, or that the use of any information, apparatus, method, or process disclosed in this report may not infringe privately owned rights; or

8. Assumes any liabilities with respect to the use of, or for damages resulting from the use of any information, apparatus, method, or process disclosed in this report.

As used in the above, "person acting on behalf of the commission" includes any employe or contractor of the Commission, or employe of such contractor, to the extent that such employe or contractor of the commission, ar employe of such contractor prepares, disseminates, or provides access to, any information pursuant to his employment or contract with the Commission, or his employment with such contractor. 
CONTENTS

Page No.

I. INTRODUCTION

1

II. PROCEDURE

III. EXPERIMENTAL

2

IV. RESULTS

V. DISCUSSION

5

REFERENCES 
The recoil ranges of fission fragments in zirconium were measured by irradiating small pieces of a Zircaloy-2 ribbon containing $492 \mathrm{ppm}$ of homogeneously dispersed $U^{235}$. The samples were wrapped in aluminum foil during the irradiation to catch the fission fragments escaping from the surface of the Zircaloy-2. Average values of 10.1 and 8.15 microns were obtained for the recoil. ranges of the median light and heavy fission fragments, respectively: these values compare quite well with values calculated from empirical equations.

\title{
RECOIL RANGE OF FISSION FRAGMENTS IN- ZIRCONIUM
}

\author{
E. R. Smith and P. W. Frank
}

\section{INTRODUCTION}

The recoil range of fission fragments in various materials is an important parameter in calculating the escape of fission products from homogeneously dispersed uranium. Recoil ranges have been measured in many gases and solids and, while the recoil ranges of fission fragments in $z$ ir conium have been estimated by empirical equations, they have apparently never been measured directly. Naturally, it is very desirable to measure the recoil ranges in zirconium because of its extensive use in reactor cores.

With knowledge of the fission product recoil ranges and the uranium content of construction materials, the fission product activities in reactor coolant water can be calculated. This is particularly important in reactor systems using large amounts of Zircaloy-2, which is known to contain small amounts of uranium from contamination. This uranium contamination will result in a background fission product level in the coolant water.

\section{PROCEDURE}

The total activity of a fission product that has escaped from the surface of a material containing homogeneously dispersed uranium is given as a function of time by

$$
A_{r}=\phi \sigma_{f} \operatorname{CSRy}\left(1-e^{-\lambda t}\right) \text {, }
$$

where

$A=$ total isotopic activity

$\phi=$ thermal neutron flux

$\pi_{f}=$ fission cross section of $\mathrm{U}^{235}$

$\mathrm{C}=$ concentration of $\mathrm{U}^{235}$ in the material

$\mathbf{S}=$ total surface of material 
$\mathrm{R}$ = recoil range of fission fragment in material

$\mathrm{y}=$ fission yield

$\lambda \quad=$ radioactive decay constant

$\mathrm{t}=$ time

$1 / 4=$ probability of recoiling from the volume SR.

The total activity of a fission product in the bulk material is given as a function of time by

$$
A_{b}=\phi \sigma_{f} \operatorname{CVy}\left(1-e^{-\lambda t}\right) \text {, }
$$

where $\mathrm{V}=$ total volume of the material.

The assumption has been made in this equation that the thickness of the material is much greater than the recoil range, so that the amount of activity that escapes is negligible compared to that which is retained.

Taking the ratio of the total isotopic activity that escapes to that which is retained in the material,

$$
R=\frac{4 V}{S} \cdot \frac{A_{r}}{A_{b}} .
$$

All that is required to obtain the recoil range of a fission product is some measure of the ratio of the total isotopic activity that escapes to that which is retained by the bulk material. Equation (3) is valid regardless of the precursors of a particular isotope, or regardless of when the activity is measured in time, because the time behavior of the activity in the bulk material is the same as that of the activity that has escaped. This method of measuring the recoil range is particularly useful since a knowledge of the neutron flux, fission cross section, $U^{235}$ concentration, and fission yield is not required.

\section{EXPERIMENTAL}

A ribbon of Zircaloy-2 containing 529 ppm of uranium, $93 \%$ enriched with $\mathrm{U}^{235}$, was used for the irradiation. The uranium was shown to be homogeneously dispersed in the Zircaloy-2 by alpha counting, uranium analysis, and gamma counting. the small pieces of ribbon. Fifty-four samples showed a standard deviation of less than $1.5 \%$ by gamma counting,

Aluminum foil was used to catch the fragments that escaped from the 7ircaloy-2, The work of Wahl (Ref 1) has shown that there is little or no emanation of the inert gases from aluminum "catchers" during decay to non-gaseous daughter isotopes. A sample of the aluminum foil was irradiated to insure that it was not contaminated with uranium. A sample of the Zircaloy-2 was wrapped in the aluminum foil and then placed in a Marlex* rabbit and irradiated in the VG-7 facility of the Materials Testing Reactor at Arco, Idaho for approximately one hour. Following the irradiation, a period of approximately 30 minutes was allowed for decay of the $2.3-\mathrm{min} \mathrm{Al}^{28}$. The aluminum foil and Zircaloy-2 were then placed in volumetric flasks and dissolved; the solution was boiled to degas it and then diluted to known volumes. Aliquots were taken for radiochemical analysis. All analyses were made in duplicate.

\section{RESULTS}

Table I gives the total activities corrected for the chemical yield of the various isotopes analyzed in the aluminum foil and the Zircaloy-2. The recoil ranges were calculated from Eq (3). Figure 1 shows the recoil range vs the isotopic mass of the fission fragment. Least squares analysis of the data gives the following equation for range as a function of mass:

$$
R=(14.50 \pm 1.04) \times 10^{-4}-(4.60 \pm 0.82) \times 10^{-6} \mathrm{M},
$$

\footnotetext{
* Marlex is a high density polyethylene type plastic produced by Phillips Petroleum Company.
} 


\begin{tabular}{ll} 
Isotope & $\begin{array}{c}\text { Zircaloy-2 } \\
\text { (cpm) }\end{array}$ \\
\cline { 2 - 2 } $\mathrm{Sr}^{89}$ & $\begin{array}{c}\text { (cp1+5* } \\
\end{array}$ \\
& $506+5$ \\
& $494+5$ \\
$\mathrm{Mo}^{99}$ & $585+5$ \\
$\mathrm{Cs}^{138}$ & $249+7$ \\
& $239+7$ \\
& $471+6$ \\
& $108+7$ \\
& $507+8$ \\
$\mathrm{Ba}^{140}$ & $196+8$ \\
& $908+5$ \\
& $629+5$ \\
& $143+6$ \\
$\mathrm{Ce}^{141,114}$ & $183+6$ \\
& $390+7$ \\
& $615+5$ \\
& $713+5$
\end{tabular}

\begin{tabular}{c} 
Al \\
(cpm) \\
\hline $439+3$ \\
$784+3$ \\
$778+3$ \\
$875+3$ \\
$352+5$ \\
$311+5$ \\
$616+4$ \\
$146+5$ \\
$605+6$ \\
$225+6$ \\
$994+3$ \\
$771+3$ \\
$132+4$ \\
$203+4$ \\
$479+5$ \\
$803+3$ \\
$928+3$
\end{tabular}

\begin{tabular}{lll}
- & \multicolumn{2}{c}{ Zircaloy-2 Sample } \\
$\begin{array}{c}\text { Vol }{ }_{3} \\
\left(\mathrm{~cm}^{3}\right)\end{array}$ & $\begin{array}{c}\text { Area } \\
\left(\mathrm{cm}^{2}\right)\end{array}$ & $\begin{array}{c}\text { Range } \\
(\mu)\end{array}$ \\
\hline $266-1$ & 1.61 & 11.1 \\
$292-1$ & 1.73 & 10.5 \\
$256-1$ & 1.53 & 10.5 \\
$292-1$ & 1.73 & 10.1 \\
$266-1$ & 1.61 & 9.34 \\
$266-1$ & 1.61 & 8.60 \\
$284-1$ & 1.70 & 8.74 \\
$256-1$ & 1.53 & 9.05 \\
$266-1$ & 1.61 & 7.89 \\
$292-1$ & 1.73 & 7.76 \\
$266-1$ & 1.61 & 7.23 \\
$292-1$ & 1.73 & 8.28 \\
$256-1$ & 1.53 & 6.18 \\
$292-1$ & 1.73 & 7.49 \\
$266-1$ & 1.61 & 8.12 \\
$256-1$ & 1.53 & 8.74 \\
$292-1$ & 1.73 & 8.79
\end{tabular}

* $261+5=0.261 \times 10^{5}=2.61 \times 10^{4}$

* $266-1=0.266 \times 10^{-1}=2.66 \times 10^{-2}$

where $\mathrm{R}=$ recoil range in Zircaloy in $\mathrm{cm}$ and $\mathrm{M}=$ isotopic mass of fission fragment in mass units.

Reference 2 gives the recoil range of median light and heavy fission fragments in various materials. It is assumed that the recoil range in any substance can be represented by

$$
R=\frac{K A}{\rho \sqrt{Z}}
$$

where

$R=$ recoil range of the material in $\mathrm{cm}$

$K=$ constant dependent only on the energy of the fragment

$A=$ atomic weight of the material in mass units

$\mathrm{Z}=$ atomic number of the material

$\rho=$ density of the material in $\mathrm{mg} / \mathrm{cm}^{3}$.

Experimentally determined recoil ranges (Ref 2 ) for median light and heavy fragments in a number of substances are given in Table II. The values of $\mathrm{K}$ for light and heavy fragments calculated from these data by $\mathrm{Eq} \mathrm{(5)} \mathrm{are} \mathrm{also} \mathrm{given.}$

It will be noted that the values of $\mathrm{K}$ for light and for heavy fragments are reasonably constant over a wide range of materials. Therefore, the recoil ranges in other substances can, with reasonable accuracy, be calculated by the following expressions: 


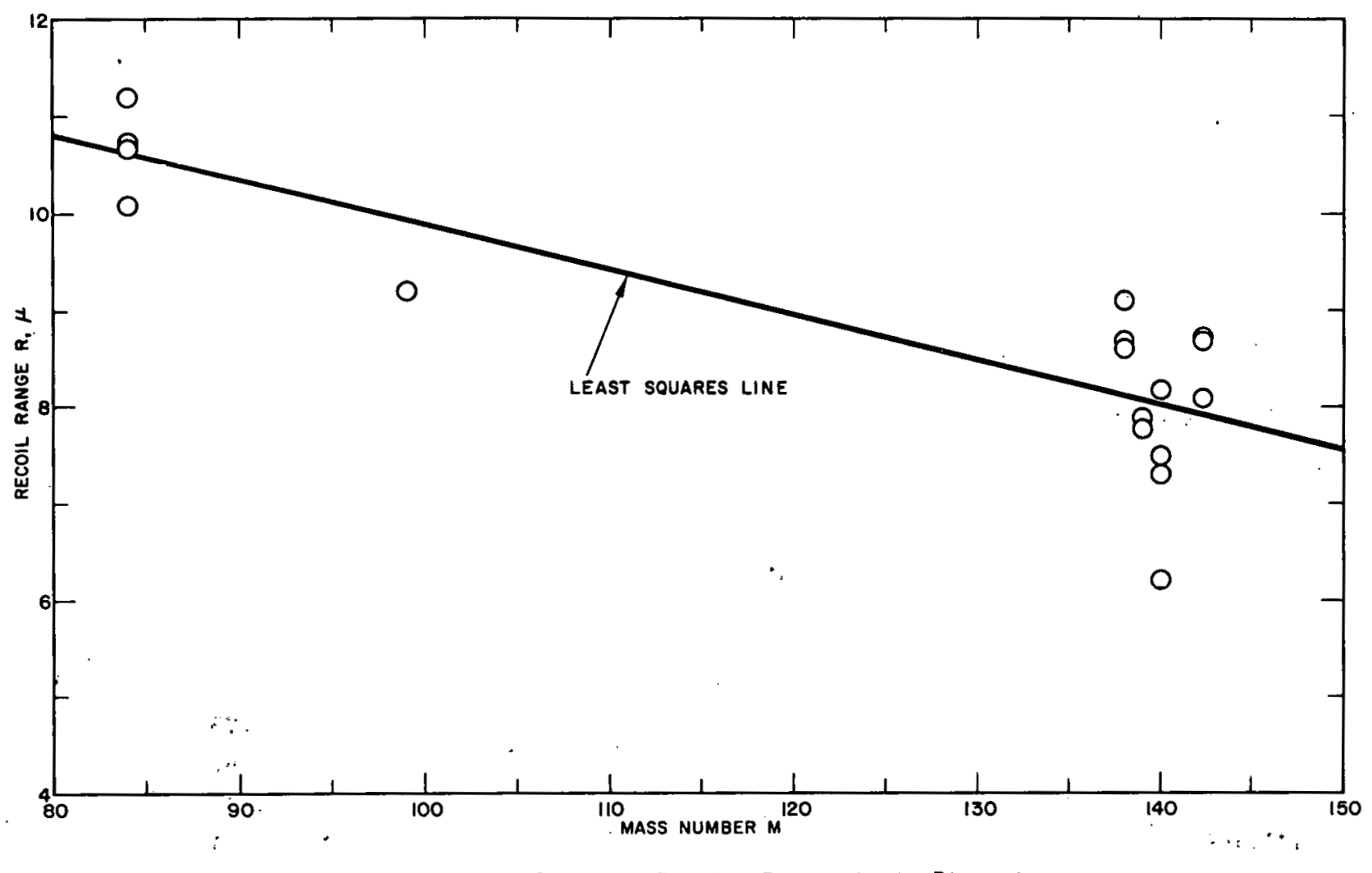

Fig. I Recoil Range of Fission Fragments in Zirconium

TABLE II

RECOIL RANGE OF FISSION FRAGMENTS IN VARIOUS MATERIALS

\begin{tabular}{|c|c|c|c|c|c|}
\hline \multirow[b]{2}{*}{ Material } & \multirow[b]{2}{*}{$\mathrm{A} / \sqrt{\mathrm{Z}}$} & \multicolumn{2}{|c|}{ Light Fragments } & \multicolumn{2}{|c|}{ Heavy Fragments } \\
\hline & & $\begin{array}{c}\mathrm{R} \rho \\
\left(\mathrm{mg} / \mathrm{cm}^{2}\right) \\
\end{array}$ & $\mathbf{K}$ & $\begin{array}{c}\mathrm{R} \rho \\
\left(\mathrm{mg} / \mathrm{cm}^{2}\right) \\
\end{array}$ & $\mathbf{K}$ \\
\hline Ḧc & 2.83 & 1.36 & 0.480 & 1.11 & 0.372 \\
\hline$\dot{A} 1$ & 7.48 & 4.10 & 0.348 & 9.45 & 0.463 \\
\hline A & 9.41 & 4.42 & 0.470 & 3.80 & 0.404 \\
\hline Ni & 11.09 & 5.61 & 0.505 & 4.54 & 0.410 \\
\hline $\mathrm{Au}$ & 22.19 & 12.37 & ט.מby & 9.00 & 0.400 \\
\hline Ave & & & $2 \pm 0 . c$ & & $0.414 \pm 0$ \\
\hline
\end{tabular}

For Hghl fragnews.

$$
R_{1} \rho=0.512 \frac{A}{\sqrt{Z}} .
$$

in $\mathrm{mg} / \mathrm{cm}^{2}$.

For heavy fragments,

$$
R_{h} \rho=0.414 \sqrt{Z},
$$

in $\mathrm{mg} / \mathrm{cm}^{2}$. 
The empirical Eqs (6) and (7) give 11.3 and $9.14 \mu$, respectively, for the ranges of median light and heavy fission fragments in Zircaloy $-2,\left(\rho=6.55 \mathrm{~g} / \mathrm{cm}^{3}\right)$. The experimentally determined Eq (4), assuming the average mass of the light fragments is 96 and of the heavy fragments is 138 , gives range values of 10.1 and $8.15 \mu$, respectively.

\section{DISCUSSION}

The average measured recoil ranges of the median light and heavy fission fragments in $Z$ ircaloy 2 were 10.1 and $8.15 \mu$, respectively. The values are only $10 \%$ lower than ranges calculated by means of an empirical equation. Therefore, it would appear that (1) the methods of calculating fission product activity in reactor systems from recoil escape are valid, and (2) that the recoil ranges of fission in many materials are given with. reasonable accuracy by the empirical equations.

\section{REFERENCES}

1. A. C. Wahl, "Nuclear Charge Distribution in Fission: Cumulative Yields of Short-lived Krypton and Xenon Isotopes from Thermal Neutron Fissions of $\mathrm{U}^{235}$, " J. Inorganic and Nuclear Chemistry, Vol 6 (1958), p. 263

2. C. B. Fulmer, "Fission Fragment Studies by Magnetic Analysis," ORNL-2320 (August 1957 ). 